\begin{abstract}
Elmar Lehmann Brinkmanship: Storytellers and the
Elmar Lehmann studied English and German at the universities of novelist Muenster, Munich, Edinburgh and Bochum, and has been Professor of

English since 1975. He teaches in the Institute for Anglophone Studies at the University of Duisburg-Essen,

Essen, Germany.

E-mail elmar.lehmann@uni-essen.de

\section{Brinkmanship: Storytellers and the novelist}

André Brink has always insisted on the importance of "imagining the real" as the writer's art and responsibility, particularly in a repressive society. In his essays of the 1970s, "imagining the real" privileges literary discourse to tell the truth. This is exactly what his novels of the same decade set out to do. Looking on Darkness and A Dry White Seasonemploy first-person narrators an anonymous novelist and an autobiographical voice - as witnesses, whose main concern is to imaginatively turn a series of events into a plot which will reveal the truth behind mere facts, and through representation protest against the apartheid state. In the 1990s, "imagining the real" takes a postmodernist turn. The novelistic voices of the earlier texts have been replaced by storytellers, e. g. Estienne Barbier in On the Contraryand Ouma Kristina in Imaginings of Sand. In their different ways, the two novels offer many, often contradictory and fantastic, versions of the past. They no longer claim to tell the truth, but are intent on "reattaching imagination to the collective memory" (G. Hartman). Key words: Literary discourse, Representation, story, storyteller.
\end{abstract}

The anonymous novelist in André Brink's A Dry White Season (1979) portrays himself as a rather disillusioned "fiction editor of [a] woman's journal" (1984b: 10) with "the habits of half a lifetime devoted to writing romantic fiction. 'Tender loving tales of rape and murder'"' (9). He is "past fifty" and "after twenty [very popular] novels" suffers from a dry patch (11).

At the end of the 1970s Brink was a well-known author with an already substantial record as a radical critic of the South African regime and its apartheid policy. One of his novels had been banned in South Africa (Kennis van die aand,1973), and two others had been shortlisted for Britain's prestigious Booker Prize (An Instant in the Wind, 1976; Rumours of Rain, 1978).

In his essays from the same decade Brink repeatedly reverts to the question of the functions of literature and the responsibility of the writer, the Afrikaans writer in particular, in a repressive society. Adopting one of the Russian Formalists' central tenets that literary language through the foregrounding of characteristic devices makes its objects appear 
strange, Brink (1983: 118) pointedly states in "Literature and Offence" (1976): "the writer's use of language differs from that of society. (...) [W] hereas society tends to enslave language the writer strives to liberate it. (...) [L]anguage in society tends to conceal, even to lie, whereas the writer uses it as an instrument in search of truth."

In "Writing against Silence" (1980), a speech delivered on the occasion of the acceptance of the Martin Luther King Memorial Prize for $A$ Dry White Season, Brink (1983: 205) claims that writing, far from being an escape, "becomes an act of defiance (...). Writing is an affirmation, not only of the individual, but, through him, of the nameless and voiceless multitude who must rely on him to define the validity of their right to be." And he adds: "Writing is one of the surest responses to the Nuremberg plea of ignorance: provided it goes beyond the surface of appearances and facts - these being the domain of the politician, the sociologist, the historian" (206).

This is the context which reveals the specific function of the novelist's persona in A Dry White Season. Confronted with the death, in a mysterious car accident, of Ben du Toit, an old friend from his university days, and with du Toit's papers ("dumped on me": 1984b: 9), he wavers between evasion and immersion (cf. 313). He is almost tempted to reject the challenge of du Toit's fate and his enigmatic character, but finally accepts the responsibility of writing down what has happened to his old friend and his search for the truth behind the deaths in detention of Gordon and Jonathan Ngubene. The gradual involvement presented in the novel's frame ("Foreword", "Epilogue") lends conviction and authority to the unnamed novelist as a "Brinkian witness" (Jolly, 1996: 21).

That latter-day catchword "authority" or, even better, "author-ity" does of course provoke misgivings:

How, one may ask, does Brink's totalitarian society produce his "writer"? What enables "the writer" - socialized as she or he inevitably is in the language of convention and consensus - to make that initial recognition of a practice of the society in which she or he lives as "offensive", the recognition that will lead to her or his transformation of pragmatic discourse into literary discourse? (Jolly, 1996:

20.)

These questions may be theoretically correct, but are nevertheless beside the point. Using a very graphic metaphor, John L. Comaroff (2001: 57) has only recently argued that "the capillary techniques of colonial 
states played a great part in sparking the dialectics of challenge and riposte, of action and counter-action, of transgression, transformation, and hybridisation." For Comaroff, the colonial state has always been "a phantasm-to-be-made-real" (58), not a system of absolute control, but a project caught in its own contradictions, when, for example, it promises to transform the colonised people into "modern citizens", albeit in a very distant future, and at the same time turns them into "unmarked ethnic subjects" (51). In line with this argument, Brink's insistence on a long and strong tradition of Afrikaner dissidence (cf. Brink, 1983: 13-35; cf. also Brink, 1992) clearly demarcates the space in which his novelistas-witness can legitimately function.

It is, therefore, not so much the authority of the novelist's personaand, ultimately, of the author himself - which has to be questioned, but rather the problematic relationship between Ben du Toit and the novelist, between the "disorderly documentation" (Brink, 1984b: 11) of du Toit's life and the story created by the novelist, between the "appearance of authenticity" on the one hand, and the "canonized literary mode" (Coetzee, 1990: 359f.) on the other.

Brink's novelist ends his story with an obviously deeply felt and programmatic statement, which echoes the passage from "Writing against Silence" quoted above: "all I am entitled to, is no more than this: to write it down. To report what I know. So that it will not be possible for any man ever to say again: I knew nothing about it" (Brink, 1984b: 316).

The novelist is, however, aware of the problems involved in reporting what he knows, because he realises that there is a wide gap between his knowledge and du Toit's experience. He has to acknowledge that there exists an almost unbridgeable positional difference between them: "What was unfinished to him is complete to me; what was life to him is a story to me; first-hand becomes second-hand. I must attempt to reconstruct intricate events looming behind cryptic notes; what is illegible or missing I must imagine" (Brink, 1984b: 33). In the same vein, the novelist has to admit towards the end of the novel that "one man lived, another wrote; one looked forward, the other back; he was there, and I am here" (313).

"Foreword" and "Epilogue" emphasise this positional difference (life vs. story; first-hand vs. second-hand; there vs. here), while at the same time glossing over it. Ben du Toit's desire to be made a witness "Report me and my cause aright!" (33) - is almost literally translated into the novelist's programmatic "To report what I know" (316), and 
then silently pushed aside in favour of the professional's time-honoured preoccupation with reconstructing and imagining. To report becomes to tell in an omniscient voice, and "the litter of another man's life" (9) is turned into a neatly structured novel. In this way, even the "documents" can be fully incorporated into the novelist's discourse. The account of the court inquest into Gordon Ngubene's death (104114) ironically flaunts the assumption that language can truthfully represent the real - but it is an assumption which is never questioned in, which indeed also permeates, the novelist's own text. The many passages from du Toit's journal (e.g. 158-163 or 208-213), despite slight traces of a diarist's style, almost as a matter of course assume a novelistic voice and can thus easily be used by the novelist to give credence to his story. Finally, even the positional gap between du Toit and the anonymous novelist is closed, when the novelist begins to suspect that, like Ben du Toit before him, he may himself be under Special Branch surveillance (cf. 315).

2

In three essays of the late 1990s, Brink reviews his early novels within the political and literary contexts of a changing South Africa. Looking back from a post-apartheid position, he describes A Dry White Season as a "novel (...) geared towards representation-as-protest" (1996b: 240), and defends this literary practice as necessary "during the apartheid years when eye-witness accounts in the form of a more or less 'realistic' literature stimulated a sense of solidarity among the oppressed while also conscientizing those not immediately involved or implicated in the struggle" (1998: 21).

In a more systematic way, he distinguishes between two concepts of history - "history as fact" and "history as fiction" - adding: "I know that in my own work I have moved from one notion to the other, not necessarily in a clear linear development, but as part of a continuing dialectic" (1996b: 231). For Brink, the move from "history as fact" to "history as fiction" acquires particular momentum in South Africa where "the change of direction signalled by the dismantling of apartheid (...) coincided with the revisions wrought in historical consciousness by postmodernism" (230f.).

The new perception of history which Brink sees at work in the South Africa of the 1990s, in historiography as well as in novel-writing, does not only result in alternative versions of history brought about by 
"decentring the conventional point of view and breaking down the master narratives of apartheid", and by giving a voice "to the silent or silenced landscapes of the past" (1999: 32). What is perhaps more important, it also leads and may increasingly lead to "an imagined rewriting of history" (37).

Drawing heavily on Hayden White's historiographical thinking and on the customary French sources, Brink discusses some of the major issues emerging from the concept of history as a textualising and narrativising process, where historical facts are inaccessible and Waterloo becomes "an act of language" (1999: 32), where realism and history as fact are left behind and historiography and fiction "begin to explore the possibilities of story" (1998: 18). In this context, "the world is perceived as story, with an endless capacity for renewal, metamorphosis, and reinvention" (19). Stories, in this sense, never claim to tell the truth, but at best offer possible versions of it; in stories, the public, the social, political and historical is absorbed by, or resolved into, imaginings fuelled by "the notoriously unreliable complex of private motivations" (1999: 39). Stories are not structured teleologically, but revolve around their blind spots (cf. $38 \mathrm{f}$.).

If all this is "a ludic enterprise" (1998: 22), it nevertheless at the same time fulfils an important function in post-apartheid South Africa:

What the reader is left with (...) in the reading of any attempt in the "new" South African fiction to reclaim some of the historical land from the sea of oblivion or of accepted versions, is the irreducible fact of textuality. But textuality does not obviate historicity or morality (...). If life itself is story-shaped, then the choices presented by story cannot be denied or avoided (...). If stories offer several versions of history (...) the imperative of choice is even more urgent, and certainly more richly textured and more rewarding (1999: 41).

Or, more strongly worded: "I certainly am convinced that without the attempt to grasp, with the creative imagination, the past and its silences, South African society as a whole may get bogged down in mere materialities, sterile rationalizations, and the narrow mechanics of retribution or amnesty" (1998: 25).

In a recently published article Geneviève Morel has addressed the issue of textuality and "history as fiction" in psychoanalytic terms and with reference to the Holocaust. Her article will allow me to look beyond Brink's argument and to focus more directly on narratological problems. 
In line with Brink, Morel discusses bearing witness as "an experience of discourse" (2002: 81), and describes one of the most important effects of testifying as " $(. .$.$) seeing the gulf between the symbolic and the$ real widen, with the risk of one or more images becoming 'the imaginary echo' of the real that preys upon the subject" (86). Witnessing, then, aims at the real, but since the symbolic (language, discourse) can never be "identical to whatever is spoken of", it follows that "every testimony implies a discrepancy with the real in question" (81) - even without the inadvertent or wilful mistakes, distortions, and lies which almost inevitably and incessantly inform witnessing. For Morel, "[i]n this hiatus between the symbolic and the real, the imaginary reveals itself as having affinities with the real that the symbolic does not have" (83).

Morel's imaginary comes close to Brink's "imagining the real", although in its earlier version (1983: 215-222), Brink still privileges literary discourse, and more particularly the novel as representing the truth behind mere facts. When, however, in the 1990s, he pleads "for the need to imagine the real" in a rapidly changing South Africa (1998: 24), he seems to be in agreement with Morel, especially when he relates the process of imagining to the magic he finds in the writings of Amos Tutuola and Ben Okri (cf. 25), or to the fictionalisation of history in the novels of John Conyngham and Mike Nicol (cf. 1996b: 235 f.).

In his postmodern theory of narrative Andrew Gibson pits the imaginary against literary discourse, and against structuralist narratology as epitomised by Gérard Genette. He discusses the imaginary as "narrative force" in opposition to form (cf. Gibson, 1996: 32-68), following Gianni Vattimo (1993: 105) who argues that "force operates against form inasmuch as it reveals and throws into crisis the violence of form" (cf. Gibson, 1996, 38-41). Form would then be characterised by (a) the symbolic as a firmly entrenched representational system, (b) the origin of speech as clearly rooted in the narrator or novelist, (c) the temporal and causal linking of events, and (d) by the creation of plot, while stories are intimately connected with the imaginary and stand in contradistinction to the novel. The storyteller, then, squarely confronts the novelist.

As shown above, it is the intervention of the novelist's persona that creates order out of a "disorderly documentation" in A Dry White Season, and it is the form of the novel as literary discourse which can claim 
to represent the truth. In Looking on Darkness (1974) and On the Contrary (1993), there is no narrator-novelist who, in Genette's punctilious terminology, could be classified as extradiegetic-homodiegetic (cf. Genette, 1980: 212ff.), rather the act of narration in the two novels is radicalised to such an extent that Brink can speak of impossible texts (cf. Brink, 1996b: 239; also Brink, 1994: 3).

The first-person narrators - Joseph Malan in Looking on Drakness and Estienne Barbier in On the Contrary - are not only imprisoned, but have been sentenced to death and are awaiting execution. Malan does write his life story:

As the end approaches and my heart contracts, it becomes more and more imperative to write it down very calmly and very clearly. So that I can empty myself completely, in order to return into myself. It's a form of discipline, like the meditations of St. John of the Cross, or Hamlet's game of madness at court. To fight my way through a web of syntactic certainties towards a final, possible glimpse of truth (Brink, 1984a: 8).

He does indeed write - but, like Dickens's David Copperfield, he writes for his eyes only, and will destroy what he has written:

I must be wary, I must protect myself, lest they [the police, the regime] use my very death to finally get hold of me through what I've written.

What I'm writing here, I shall destroy as I go on. (...) Fortunately the paper is very thin and it will be easy to flush it, page by page, down the toilet (9).

What "they" and we are left with is a selection of Shakespeare's sonnets, slightly altered or not correctly remembered (cf. Brink, 1984a: 10, 395-400).

Estienne Barbier on the other hand is in absolutely no position to write "in this stinking Dark Hole of the Castle" in mid-18 ${ }^{\text {th }}$-century Cape Town: "in this ultimate letter, this quite impossible letter - I have neither pen nor paper and it is too dark in here to see-I address myself, Rosette, to you" (Brink, 1994: 3).

While in Looking on Darkness the very first sentence - "To know who I am." (Brink, 1984a: 7) - leaves no doubt about the origin of the text, and its impossibility is never touched, a short chapter deeply steeped in Jacques Derrida's concepts and terminology (cf. Brink, 1994: 4, 375; chapter 2 and "Acknowledgments"), highlights the impossibility of $O n$ 
the Contrary through collapsing some of the well-known binary oppositions endlessly "critiqued" by postmodernists:

This is just a story. I am not even sure that I am telling it (...) I am absence. All I have, think I may have had, is this story. Multiplying, in the telling, into a host of others. And even that may be illusory. Perhaps already I am told as much as telling. Perhaps my very attempt to imagine what has happened to myself (...) is no more than the effect of someone else, in another place, another time, fifty years, a century, two hundred and fifty years from now, who knows, God knows, trying to imagine me (Brink, 1994: 4).

Much like the anonymous novelist in A Dry White Season who reconstructs and imagines du Toit's life in the service of truth, and like Martin Mynhardt in Rumours of Rain (1978), who prides himself on his youthful essays in novel-writing and therefore, almost naturally, attempts to solve his problems in a novelistic way, Joseph Malan does certainly produce a novel, whereas Estienne Barbier is a born storyteller and inveterate liar (cf. the full and typically $18^{\text {th }}$-century title: $O n$ the Contrary. Being the Life of a Famous Rebel (...) and Liar).

Joseph Malan's "impossible" text is a novel complete with all the conventional properties of the genre, and the characteristics of a fictional autobiography. There is the carefully balanced and mutually enlightening relation between private and public - in Malan's love story under the threat of the Immorality Act (cf. Brink, 1984a, especially chapter 6), in the story of his ill-fated actors' group harassed by racism, hampered by censorship, and under constant Special Branch surveillance (cf. chapters 4 and 6 ). Two early chapters ( 2 and 3 ) present the family history of the Malans, and extensively dwell on the story of the narrator's childhood and youth, the years in Britain and the return to South Africa in 1966, the year District Six was demolished under the Group Areas Act. Not surprisingly, the actors repeatedly discuss the role of the arts, and of the theatre in particular, in an apartheid-ridden South Africa. The whole text, not least the scenes of torture (cf. chapter 5), are replete with intertextual references ranging from Aristophanes to Beckett. The novel parades its literariness. The literary discourse is obviously meant to give dignity to a silenced victim and, more importantly perhaps, to legitimise the representation of a victim's character and life in racist South Africa. For Brink in the 1970s, Looking on Darkness seems to explore the very limits of the genre in the sense of "representation-as-protest". 
Twenty years later in On the Contrary, it is again the act of narration (the space between death sentence and execution) which delimits the narrator's discourse. However, while in Looking on Darkness the why of Malan killing his English lover Jessica Thomson and his "To know who I am" foreground the sequence of events and add up to a characteristically novelistic plot (a fictional autobiography), in On the Contrary the three parts, i.e. the three journeys into the interior, are not so much a sequence but rather mirror each other: "For the third time I retrace the trajectory already drawn twice before across the dusty land" (Brink, 1994: 349). Instead of a sequence we find repetition as variation through a proliferation of stories.

Barbier presents vastly different, often utterly contradictory versions of his journey to, and arrival at, the Cape (cf. chapters 5, 36, 44, etc.) and, almost like a running theme, of his early life in Europe. His "imagined" account of the first expedition into the interior hinges on, and shows traces of, two other versions: of the official journal submitted to the Cape authorities - "the correct and proper truth" (40), as he paradoxically calls it - and of his own journal, erased and replaced in the rewriting of the official version (39-41). In fact, the "impossible letter" we read is supposed to be another version of a long letter addressed to the Governor of the Cape - or rather, not a letter but "a book in three parts" - which itself only recapitulates "everything [Barbier] had told [the Governor] before" (339).

The storyteller continuously comments on what he is doing: "This fascinates me: how each story displaces others, yet without denying or ever entirely effacing them" (134). He knows that "the truth is environed by the lie, accessible only through the adventures of trying to tell it" (200) and that there "is always a new discovery in the retelling" (8).

Bearing in mind Morel's discussion of witnessing and Gibson's "narrative force", one realises that in On the Contrary storytelling becomes the force which disrupts the form of the novel and recurring images serve as the nuclei around which the innumerable stories revolve. Without doubt, the focal image is Rosette, either from Bengal or from Africa, but certainly from the "House of Slaves" (70), the addressee of Barbier's "impossible letter" and herself a supreme storyteller. It is Rosette who tells the story of a woman born from an egg "in the heart of Africa" (chapter 45), retelling it at the beginning of Barbier's third journey (chapter 269); and in his "Acknowledgements" the author adds what one might call a very short history of sources and parallel versions (375). It is Rosette who in their "final meeting in the wilderness" (183), 
in "that unreal night of tales" (184) tells the story of the "Storyteller", a woman whose tales "spoke a world into being" (184), and of the forgotten story we all try to recover through perpetual telling and retelling.

Finally, Rosette - woman, storyteller, slave, Africa - becomes an allencompassing image for Barbier: "Rosette is no longer a woman (...) Rosette is now the name of everything I have to do" (355). Leaving behind his constant companions and role models (cf. chapter 30 ) Jeanne (or Joan of Arc), rebel and victim, his familiar and his stern admonisher, and "the narrow gentleman from La Mancha" (36) in the "soothsaying book" Don Quixote (121) - he undertakes the last stage of his final pilgrimage: "I am in need of absolution. A necessary journey to redeem myself. For this I have to reach those we expelled, and scattered, and attacked, and insulted. Above all I have to find you" (350). In the end, or rather in the "rewriting of [his] whole history" (339) and, of course, in the being told and retold "two hundred and fifty years" later (4), the $18^{\text {th }}$-century rebel and early Afrikaner dissident (cf. Brink, 1999: 36) turns, is turned, into a late $20^{\text {th }}$-century (white) Everyman in a novel on the brink of dramatic changes in South Africa. The stories centre on elusive, enigmatic Africa, and the novel's desire and hope is the perhaps only remote possibility of an at least minimal plot: breaking "the cycle of hate and vengeance" (Brink, 1994: 358).

Turning from the "imagined rewriting" of an $18^{\text {th }}$-century rebel's life to the "silenced landscapes" of women (cf. Wenzel, 2004: 78-80), Brink in Imaginings of Sand (1996) creates yet another novelistic context for the storyteller. The first-person narrator, Kristien Müller, returns to South Africa in April 1994 and has to come to terms with the violence, especially the violent deaths in her own family, and with her position and attitudes vis-à-vis the enthusiastic hope surrounding the first democratic election in the country. At the same time, she intently listens to the stories told by Ouma Kristina on her deathbed. In this way, two very different discourses are juxtaposed: (a) the circumstantial depiction of a momentous situation from the point of view of someone who at once belongs and is a stranger after an absence of more than a decade; (b) the stories full of magic and wonder which together present a female genealogy and a South African past. These stories interspersed in Kristien's narration are not so much an oblique commentary on the 1994 events, but rather the liberating experience of alternatives. The narrator in this novel becomes the audience of the storyteller's imagined retelling of history, and the novel turns into the receptacle and transmitter of "rememory", to borrow a felicitous term from Toni Morrison's Beloved (1988: 35f.). 
Geoffrey H. Hartman (1995: 81) maintains that "[w]hat is viable in the notion of collective memory tends (...) to be artistic" and he insists that literature's indispensable task is to "respond to the challenge of reattaching imagination to the collective memory" (83). Brink's novels, whether in the guise of cautious realism or tentative postmodernism, and his storytellers do respond to this challenge.

\section{Bibliography}

Comaroff, John L. 2001. Reflections on the Colonial State, in Africa and Elsewhere: Fractions, Fragments, Facts and Fictions. In Abebe Zegeye (ed.). Social Identities in the New South Africa. After Apartheid, vol. 1 (Social Identities South Africa). Cape Town: Kwela Books, 37-80.

Coetzee, Ampie. 1990. Literature and Crisis: One Hundred Years of Afrikaans Literature and Afrikaner Nationalism. In Martin Trump (ed.). Rendering Things Visible. Essays on South African Literary Culture. Johannesburg: Ravan Press, 322-366.

Brink, André. 1978. Rumours of Rain. London: W.H. Allen.

. 1983. Mapmakers: Writing in a State of Siege. London: Faber.

.1984a [1974]. Looking on Darkness. London: Fontana Paperbacks (orig. Kennis van die aand [Afrikaans, 1973]. Cape Town: Buren).

_. 1984b [1979]. A Dry White Season. London: Fontana Paperbacks.

1. 1992. Afrikaners and the Future. Granta 40 (Summer), 189-193.

1994 [1993]. On the Contrary. London: Mandarin Paperbacks.

1996a. Imaginings of Sand. London: Quality Paperbacks.

1996b. Reinventing a Continent. Writing and Politics in South Africa 1982-1995. Introd. by Nelson Mandela. London: Secker \& Warburg.

. 1998. Interrogating Silence: New Possibilities Faced by South African Literature. In Derek Attridge and Rosemary Jolly (eds.). Writing South Africa. Literature, Apartheid, and Democracy, 19701995. Cambridge: Cambridge University Press, 14-28.

— 1999 [1998]. Stories of History: Reimagining the Past in Post-apartheid Narrative. In Sarah Nuttall and Carli Coetzee (eds.). Negotiating the Past: The Making of Memory in South Africa. Oxford: Oxford University Press, 29-42.

Genette, Gérard.1980. Narrative Discourse. An Essay in Methodology. Trans. Jane E. Lewin, foreword by Jonathan Culler. Ithaca, N.Y.: Cornell University Press.

Gibson, Andrew. 1996. Towards a Postmodern Theory of Narrative (Postmodern Theory). Edinburgh: Edinburgh University Press.

Hartman, Geoffrey H. 1995. Public Memory and Its Discontents. In Marshall Brown (ed.). The Uses of Literary History. Durham: Duke University Press, 73-91.

Jolly, Rosemary Jane. 1996. Colonization, Violence, and Narration in White South African Writing: André Brink, Breyten Breytenbach, and J.M. Coetzee. Athens: Ohio University Press.

Morel, Geneviève. 2002. The "Melancholization" of the Witness: The Impotence of Words, the Power of Images. In Okwui Enwezor et al. (eds.). Experiments with Truth: Transitional Justice and the Processes of Truth and Reconciliation (Documenta11_Platform2). Ostfildern-Renit: Hatje Cantz, 79-96.

Morrison, Toni. 1988 [1987]. Beloved. London: Pan Books.

Vattimo, Gianni. 1993. The Adventure of Difference. Philosophy after Nietzsche and Heidegger. Trans. Cyprian Blamires with Thomas Harrison. Cambridge: Polity Press.

Wenzel, Marita. 2004. The Latin American Connection: History, Memory and Stories in Novels by Isabel Allende and André Brink. In Hein Viljoen \& Chris N. van der Merwe (eds.). Storyscapes. South African Perspectives on Literature, Space \& Identity. New York: Peter Lang, 71-88. 